\title{
What Kind of a Girl Does Science? The Construction of School Science Identities
}

\author{
Nancy W. Brickhouse, ${ }^{1}$ Patricia Lowery, ${ }^{1}$ Katherine Schultz ${ }^{2}$ \\ ${ }^{1}$ School of Education, University of Delaware, \\ Newark, Delaware 19716 \\ ${ }^{2}$ Graduate School of Education, University of Pennsylvania, 3700 Walnut \\ Street, Philadelphia, Pennsylvania 19104-6216
}

\section{Received 15 December 1998; accepted 14 December 1999}

\begin{abstract}
A view of science as a culturally-mediated way of thinking and knowing suggests that learning can be defined as engagement with scientific practices. How students engage in school science is influenced by whether and how students view themselves and whether or not they are the kind of person who engages in science. It is therefore crucial to understand students' identities and how they do or do not overlap with school science identities. In this paper, we describe four middle school African American girls' engagement with science. They were selected in the 7th grade because they expressed a fondness for science in school or because they had science-related hobbies outside of school. The data were collected from the following sources: interviews of students, their parents and their teachers; observations in science classes; journal writing; and focus groups. These girls' stories provide us with a better understanding of the variety of ways girls choose to engage in science and how this engagement is shaped by their views of what kind of girl they are. (C) 2000 John Wiley \& Sons, Inc. J Res Sci Teach 37: 441-458, 2000.
\end{abstract}

Girls are alienated by science. Science is masculine, competitive, objective, impersonal-qualities that are at odds with our images of what girls are. The more masculine the branch of science (e.g., physics), the less likely it is that girls will like it or do well. Girls take science courses that are required of them; they rarely choose those that are not required. Teachers rarely call on girls in class. If they do, they ask girls easy questions because they expect less of them. Girls are interested in pleasing their teachers and are thus more likely to follow the rules rather than invent them. Girls prefer to learn in cooperative classrooms that encourage engagement with peers. Although girls may prefer small groups, those classes are dominated by boys who tend to take charge, manipulate the equipment, and leave them to play the role of scribe. Girls are disadvantaged in science before they even get to school because they are encouraged to play with dolls rather than blocks. They rarely accompany their fathers while they fix items around the house. Parents rarely purchase chemistry sets or microscopes for their girls, nor do they take them camping. As adolescents girls become interested in being attractive to boys, they take on more feminine roles that often exclude science. Girls become women who cannot and do not engage in science.

Correspondence to: N.W. Brickhouse

Contract grant sponsor: Spencer Foundation 
This is the story we tend to hear about girls. Each of these claims is well known and supported by research. It is a story that was constructed by the comparison of boys and girls; studies which focused on the differences between the two groups. For example, a recent study by Adamson, Foster, Roark, and Reed (1998) reports that elementary-grade boys are more likely to choose science fair projects related to the physical sciences, whereas girls are more likely to choose projects related to the biological or social sciences. Other research (Greenfield, 1996) using National Educational Longitudinal Study of 1988 (NELS-88) data reports that middle school females have less positive attitudes about science and participate in fewer relevant extracurricular activities than males. Kahle, Parker, Rennie, and Riley (1993), in reporting the results of an equity intervention project, claimed that boys often dominate in science classrooms, particularly in handling the equipment during science labs. Baker (1998), in reviewing the literature on equity issues in science education, provided an extensive summary of the research on how boys and girls differ in relation to science education.

The research that constructed the typical stories we tell about girls in science has been important in terms of creating an awareness that girls generally do not fare well in science classes. Furthermore, it illustrates for us that this inequity is a social problem that can be fixed. However, the above story has created a stereotype of girls and boys that fits no one in particular and presents a homogeneous image of both girls and boys as science learners. In other words, this research does not help us understand the diversity that exists among both boys and girls. Research of this nature has led some to call for research that accounts for the complexity of the meaning of gender and the diverse ways in which it is enacted (Gaskell, Hepburn, \& Robeck, 1998; Krockover \& Shepardson, 1995; Rennie, 1998; Weedon, 1987).

Until now, stories about the diverse roles and paths girls take have not been told. We want to tell those stories. These are stories of what Aikenhead (1996) described as cultural border crossings." That is, these are stories that tell us about how girls cross the borders between the subcultures of the family and peers and that of school and school science in particular (Costa, 1995). We want to tell you about Tanisha, who is always called on in science class; Sandy, who is her father's only child and shadows him as he works on cars; Sheela, who is not only good at science, she's good at everything; and Chandra, whose greatest accomplishments in science were acquired through extraordinary social skills.

Our approach is reminiscent of that of Shapiro (1994), who created detailed personal profiles of students. Based on an individual constructivist orientation, she argued for the importance of understanding a variety of personal factors in teaching children. We agree with Shapiro that it is important for teachers to understand personal orientations and for teachers to build on the strengths of learners. Our approach is similar in that we are also constructing detailed profiles of students, but differs because we view the personal as also being social and political. The orientations described by Shapiro do not all have the same currency in school science.

Student identities, as well as teacher responses to these identities, are shaped by gender, race, and class relations, among other factors. The influences of these factors are complex but nonetheless powerful. Fordham (1996) showed how ethnic identity interacts with school success for both low- and high-achieving African Americans. Whereas low-achieving African American students tend to construct oppositional identities to school, high-achieving female African Americans often become successful by denying their African American identities and becoming invisible-like White girls. Although Fordham's work has been important in helping us understand ethnic identities and success in school, it deals little with specific subject matter or with the diversity of ways in which students may engage in it.

In this article, we use four case studies to tell stories about middle school African American girls' identities as science students and how schools respond to these identities. We begin by describing how work on identity formation has guided our thinking on how students learn 
science. Following a description of the study and methodology, we present four cases of girls' engagement in school science that illustrate a range of identities, many of which are unlike those reported in the research literature. We also describe how these identities are shaped by gender, race, class, and culture and how these identities affect the girls' success in school science.

\section{Learning Science and Acquiring (Science) Identities}

Learning science typically has been viewed as a process of acquiring an understanding of science and applying these understandings in new situations. Decades of research on learning has led science educators to believe that even in classrooms with caring, educated teachers, students can work very hard to learn the concepts yet still frequently leave science classes with misunderstandings about many of the most important concepts in science (Duit \& Treagust, 1998). Increasingly, science educators have come to recognize that students are always engaged in activities that lead to learning (Duit \& Treagust, 1998). The issue for us is not whether they are learning, but what they are learning in science classes.

A critical concern for us is the extent to which, when we observe in local classrooms, it appears that what students are learning in science classrooms has very little to do with science. We see considerable learning about how to convince a peer that one can be trusted or how to keep oneself amused when one is bored. At times, we would find ourselves thrilled to hear a student state a classic misconception, because at least that would be evidence of engagement with the subject matter of science. Whereas researchers seem to be primarily concerned with whether students are internalizing the completely accurate and useful scientific view of the world (Taylor, 1998), we have not sufficiently attended to the more fundamental question of whether students see themselves as the kind of people who would want to understand the world scientifically and thus participate in the kinds of activities that are likely to lead to the appropriation of scientific meanings.

The literature on situated learning which does not separate issues of identity from issues of learning is helpful here. Lave (1992) proposed that we think of learning as an apprenticeship, where students forge identities in communities of practice:

Learning is, in this purview, more basically, a process of coming to be, of forging identities in activity in the world. In short, learners are never only that, but are becoming certain sorts of subjects with certain ways of participating in the world.... Subjects occupy different locations, and have different interests, reasons and understandings of who they are and what they are up to. (Lave, 1992, p. 3)

In other words, to understand learning in science, we need to know much more than whether students have learned the proper explanation for how plants make their food or why there are seasons. We need to know how students are engaging in science and how this is related to who they think they are (what communities of practice they participate in), e.g., a good student, a basketball player, a gossip, and who they want to be (what communities of practice they aspire to), e.g., a teacher, a mother, a gemologist, an obstetrician. As students transform their identities, the requisite knowledge and skills for being a part of the new communities are learned. Thus, if students are to learn science, they must develop identities compatible with scientific identities.

Individual identity is not necessarily either single or stable. A person can be a part of or aspire to many different communities simultaneously. William James noted this:

... we may practically say that he has as many different social selves as there are distinct groups of persons about whose opinion he cares. He generally shows a different side of himself to each of these different groups. (cited in Goffman, 1958, p. 31) 
Furthermore, the communities students participate in are very likely to change, particularly for adolescents who have not yet fully formed an entirely stable view of themselves. Thus, it is important to examine students' multiple social identities. We need to understand how students are constructed and construct themselves as girls, as members of a particular racial of ethnic group, as a "good" girl, as an athlete, and how these identities overlap in important ways with students' views of scientific identities.

Here we use "social identity" following Lloyd and Duveen (1992).

... children are born into a particular society and become competent, functioning individuals with particular social identities to the extent that they re-construct for themselves the social representations of the significant groups in their society. (p. 27)

The tasks for students are to decide which groups they identify with, what kinds of persons they wish to be as a part of each group, and what is required to become those kinds of persons.

This construct of identity is useful in several other ways as well. It accounts for the importance of both individual agency as well as societal structures that constrain individual possibilities. We know that individuals are not free to be anyone they wish. However, we also know that society does not totally define a person. Although the process of identity development is an individual one, it is a process that is socially situated, giving rise to meanings and positionings that are part of the social world. Students' actions then become an expression of their social identities because it was their social identities that have organized their activity (Lloyd \& Duveen, 1992).

This view of identity also allows us to examine variation within social categories. Thus whereas individuals must adopt a social gender identity,

... different gender identities are available within sex groups. Masculinity and femininity have a variety of definitions, and these different social gender identities provide children with a means for orienting themselves in the social world of the classroom in the present, and with a pathway towards the development of their gender identities in later years. (Lloyd \& Duveen, 1992, p. 179).

For example, Fordham (1997) described a culturally distinct route to womanhood among African American women. Unlike many middle-class White communities, in African American communities women are not silent. When African American girls enter school, they are often perceived by their White teachers as loud. To do well in a school governed by mainstream rules, this behavior has to be unlearned. One of the common features of high-achieving Black girls is they work hard and are silent. This silence has been described as having the effect of passing as a White female (Fordham, 1996). Thus, although issues of coming to voice (Belenky, Clinchy, Goldberger, $\&$ Tarule, 1986) are an issue for all girls, they are expressed in different ways depending on race.

Thinking of learning as the transformation of "identity-in-practic" (Lave, 1998) leads us to question the nature of the communities of practice. The standard view in science education is that we want to enculturate students into the practices of scientists (Roseberry, Warren, \& Conant, 1992). Research scientists set the standard for how to engage competently in science. There are two problems with considering research scientists as the community of practice into which we want students to forge identities.

One problem is that this community is too distant and irrelevant to students. Communities of practice relevant to the formation of scientific identities must be present and accessible-for example, identification with other students engaged in science or identification with a father who brings a child into his work of fixing a car. Relevant communities of practice are multiple, over- 
lapping, and dynamic. In other words, there are many communities of practice that would be relevant to the forging of scientific identities. Furthermore, the nature of these communities would likely change with time as students' experiences and opportunities change.

The second problem with the assumption that research scientists are the appropriate community of practice is that this is in excessively narrow view of what it means to engage in science. There are many people who competently engage in science as citizens, health care consumers, workers, lawyers, or gardeners. These forms of engagement with science need to move out of the periphery of science education to be taken seriously as legitimate participation in science (Eisenhart \& Finkel, 1998).

Brown, Collins, and Duguid (1989) argued that in the case of learning in school, the most relevant community is that of the school itself. The kinds of practices students are offered to engage in at school often have little connection to communities outside of school. For the most part, students are not engaging in science, they are engaging in school science. School science often does not allow for varieties of approaches and directions. Furthermore, science classes are places where students are engaged in a large variety of activities that may appear to have little to do with science. These activities may, however, be crucial in understanding how students are constructing identities relative to school science.

In this study, we wanted to understand how female students form scientific identities. We chose students to participate in the study who expressed an interest in science, yet were most likely to be viewed by society as people who are not scientific, i.e., girls of color from poor or working-class backgrounds. We want to know the kinds of identities these girls construct for themselves and how these identities overlap with scientific identities.

\section{Context of the Study and Data Collected}

Plotkin Middle School, where these data were collected, is a large school of seventh- and eighth-graders. Like the other public schools in this East Coast county which were under courtordered desegregation plans since 1978 at the time of the study, the school was approximately $35 \%$ African American, 65\% White. (The court order was lifted in the fall of 1996. The state is currently implementing a new choice plan. However, at the time of this study, the choice plan had made minimal impact on the actual student composition in the schools.) Fifteen percent of the students at Plotkin receive free or reduced-price lunches. Although the school is located in a college town in a mid-Atlantic state, few professors' children attend this school. Many opt for private education; some opt (by moving into the right neighborhoods) for a different public school that is perceived to be better. Based on eighth-grade writing assessment results, Plotkin is considered a low-achieving school with scores well below the average for both the district and the state.

These data were collected over 18 months (December 1997 to June 1998). Twelve seventhgrade girls at Plotkin Middle School who described themselves as interested or successful in science in a written autobiography were selected to participate in the project. Our intent was to examine how these girls engage in science, both in and out of school, and how this engagement changed through middle school and high school. Girls were invited to be a part of the project if they expressed an interest in science either in or out of school and if they came from low-income or minority backgrounds. Both class and race were difficult to discern. Many of the girls did not fit neatly into class or race categories. For example, some girls had a White or mixedrace parent and did not really know whether to identify themselves as African American or mixed race on the fill-in-the-blank form we gave them. Although the ambiguity of race and class labels creates intriguing dilemmas for these girls and for us as researchers, for the present purposes we describe their race/ethnicity as they described it to us. 
The girls were selected from two seventh-grade teachers' classes. One of these teachers, Ms. Dawson, has unusually close relationships with her students and taught them for both seventh and eighth grades. Ms. Dawson is African American and has been teaching for 7 years. Ms. Dawson talks very candidly about the fact that many people think she is White when they first meet her. Her students, however, know that she considers herself African American because she makes a point of having them get to know her personally. She is married to a dark-skinned African American whom many of the students have met. Of the four girls highlighted here, only Chandra was taught by Ms. Dawson.

The other seventh-grade teacher, Ms. Heath, is a recent graduate from an elementary teacher education program and used many inquiry-oriented science experiments. The girls in our study called them labs, perceived themselves as successful in doing the labs, and thought they were enjoyable. Ms. Heath had a baby midyear in the first year of the project. The long-term substitute struggled with the class for the remainder of the year. The girls found her instruction, which consisted mostly of reading the textbook and answering questions, to be dull. The teacher spent more time dealing with discipline problems than with teaching. For the eighth grade, the girls had Ms. Taylor for science. She was a new teacher, yet successful with them. She was a recent graduate of a secondary teacher education program in which gender equity was a major component. She was very interested in making sure her science classes were girl-friendly and made good use of her strong subject matter knowledge.

In the seventh grade, the girls were given journals and asked to write about their experiences in school science and at home and in the community. We conducted biweekly observations of the girls in their science classes, two individual interviews with each girl, two focus group interviews, an interview with their science teachers, and an interview with a parent of their choice. We also collected their journals.

During the girls' eighth-grade year, we looked for ways to keep them interested in the research project. Although they were asked to write in journals about their participation in science, we did not find this to be an assignment that either kept the girls interested or provided us with useful data on their engagement with science. Afterschool pizza parties seemed popular, so we had four of these, including some time for focus group interviews about their participation in science in or out of school, as well as their plans for the future. We provided a few opportunities to give the girls access to additional women involved in science (e.g., pilots, engineers) and did other things together just for fun. We continued biweekly observations of the girls in their science classes and interviewed both them and their science teachers at the end of the year.

Whenever possible, we welcomed opportunities to have a positive influence on the girls and documented these influences in some detail. For example, simply being a part of the project enhanced the girls' views of themselves as successful in science. They know they were selected because we believed they would provide us with stories of girls' successful engagement in science.

\section{Understanding Performances}

For each girl in the study, we have many different kinds of data from which we composed case studies to describe what kind of girl she is, what she aspires to be, and her view of science. Our study may be somewhat novel in the way that we view our data. First, we recognize that describing someone's identity requires interpretations of data that are indirect:

... the "true" or "real" attitudes, beliefs, and emotions of the individual can be ascertained only indirectly, through his avowals or through what appears to be involuntary expressive behavior. (Goffman, 1958, p. 1) 
Furthermore, these data are generated in a context in which we are not merely flies on the wall; we are an audience for the girls who present themselves to us. When we observe the girls in science classes, we observe not only how they present themselves to us, but also how they present themselves to their teachers and peers. When we interview them with a parent, we see them interact with yet another audience: an adult audience of parent and researcher. Here, we find the dramaturgical metaphors and principles outlined by Goffman (1958) for sociological analysis to be extremely helpful. He described everyday activity as a performance in which people are not only acting out who they are, but are playing particular roles that are consistent with both who they think they are and who they aspire to be. Thus, the metaphor of a performance does not necessarily imply insincerity.

In a sense, and in so far as this mask represents the conception we have formed of ourselves - the role we are striving to live up to-this mask is our truer self, the self we would like to be. In the end, our conception of our role becomes second nature and an integral part of our personality. We come into the world as individuals, achieve character, and become persons. (Park, 1950, p. 249)

Thus, the girls are viewed as performing multiple roles of good student, tough girl, faithful friend. The researchers are, of course, playing a role that involves asking many questions, writing copious notes, and in general being supportive of the girls in any way that arises.

It is possible, of course, for the cynical actress to manipulate her audience. However, there are also ways of judging the sincerity of the performance. For example, we examined how the performance varied from one audience to the next. Thus, we gained access to performances for peers, teachers, parents, and researchers. We also looked for coherence in manner, activity, appearance, and talk. For example, in describing a social girl, we would note not only what she actually does with peers, but also her appearance, ways of talking about herself with peers, and adult and peer perspectives. Whereas we would expect that the girls' presentations would differ somewhat from one audience to the next, we should be able to explain the reasons for differences.

Cases were written for each girl based on these performances, as described in field notes from classroom observations, interviews of the girls, and focus group meetings. In addition, performances from parents and teachers were used to help us understand how other people view the girls. We wrote the cases, initially including as much description of the girls' views of their engagement in science as was supported by the data. For the purpose of the report, we include only those aspects of the girls' identity as could be supported by multiple data sources.

\section{The Cases}

Here, we present four cases from this larger data set. These four cases were selected because they were exemplary of diversity in girls' identities and their engagement in school science. One girl is an ideal student; the others are not. Two of the girls have considerable sciencerelated out-of-school interests; two express interest primarily in school science. The first two girls are of particular interest because they are remarkably similar in background, yet construct different identifications with school science.

\section{Sheela}

Sheela lives with her mother and brother, who is 5 years younger, in a new townhouse located in a large development. On our form, she described herself as African American. Sheela's 
mother graduated from a vocational high school and is the manager of a fast-food restaurant. Although Sheela's father does not live with them, she sees him regularly. He is a supervisor of computer operations at a local bank. He takes Sheela and her brother fishing and to science museums.

By school standards, Sheela is nearly perfect in both appearance and behavior. Our initial and continuing reaction whenever we see Sheela is to straighten our backs. She is petite and her posture is straight. Sheela is always immaculately groomed and dressed. We have never seen Sheela violate any of the teacher's rules. Although she talked to her friends before class began, she was always in her seat and quiet when the bell rang. She was the only girl in our group who consistently brought her journal to meetings of the research group. However, she rarely spoke or shared what she had written in her journal, and showed it to us only after someone else shared her own writing. Although she did not interact with the other girls in the research group, she claimed them as friends.

Sheela's engagement in school science was largely dictated by the instruction she was given. She consistently followed the teacher's directions and completed all the required tasks. She was not selective in terms of choosing to engage in some tasks but not others. There was little interaction between Sheela and her teacher.

Sheela was in the eighth-grade science class which consisted of students who were tracked in upper levels for mathematics and language arts classes. Her grades in science class were consistently A's. She was very attentive but never volunteered to talk in class. She spoke when spoken to-which was rare. Her friends came to her. She was often the leader in her racially integrated science groups and worked well in teams. Sheela described the ineffective long-term substitute in her journal with no evaluative comments. Although it was clear to us that Sheela preferred the more lab-oriented instruction of her initial seventh-grade teacher, the criticism was subtle and would have been missed by anyone who did not understand the context in which she was writing.

Although Sheela did not draw attention to herself-much like the high-achieving girls in Fordham's book (1996) — she was very confident. When asked what she learned the most about in eighth-grade science, she responded:

I don't know. I really learned a lot about everything because I'm really good in science. Because I've gotten A's all year. So I'm really good at it. I'm good at everything. (Student seventh-grade interview)

Sheela's view of her competence is shared by her mother, who explained that Sheela could write her name when she was 2 years old. She also described her daughter as creative because of her ability to make up stories. Finally, Sheela's mother was particularly proud of the game Sheela created using magnets in science class in the seventh grade. Sheela's strong academic interests and orientation were also seen to be demonstrated in her role of teacher, a role she has taken on since she was about 3 or 4 years old. According to her mother, Sheela taught her little brother to read when he was 3 and continues to be the leader of all other children in the neighborhood. The important issue embedded in these early childhood stories is the expectation and construction of an academically gifted and obedient schoolgirl.

Sheela is successful in school. She credited her good understanding of science with her obedience to the rules of the class. She describes this as follows:

Science is easy. All you have to do is sit there and listen instead of doing what you're not supposed to be doing. You have to listen and then you'll understand it. (Student seventhgrade interview) 
Although she saw herself as good at science in school, she did not necessarily assume that this meant she would be a good scientist.

[My teacher] keeps saying that sometimes things aren't that easy, that there are still scientists trying to figure out, are there more than 109 elements on the Periodic Table or something. It's almost like the other scientists that have jobs as scientists, their jobs are harder than what we have to do because we are just doing simple stuff. (Student eighthgrade interview)

To some degree, Sheela's science teacher (Taylor) concurred with the view of Sheela as a gifted student. Although Sheela's science teacher also taught Sandy and Tanisha, Sheela was the only one she recommended for the honors track-designed for students who will definitely attend college and need adequate preparation. However, her teacher's reasons for this judgment had less to do with ability than study habits. The honors track is described as requiring independent, self-motivated learners. Of the research project girls who were her students, this teacher believed only Sheela fit that description.

Sheela exhibits many of the traits of high-achieving black girls described by Fordham (1996). She is quiet and works hard. She differs from Fordham's descriptions in that she appears to be mostly self-motivated and appears relatively happy with her current status. She is an excellent student in every subject. She likes science because she likes all her school subjects.

\section{Tanisha}

Tanisha lives with her mother and older brother in a new single-family home in the same neighborhood as Sheela. Her family has lived in this house 1 year. In the past, they moved a lot. Tanisha spends a lot of her time in the finished basement, where a huge television dominates the room. On the form we gave her, Tanisha described her race/ethnicity as "African American/ mixed."

Tanisha's mother is young and fair-skinned, with delicate features. She is muscular, attractive, and well dressed. Tanisha's mother said her own family expected her to be a doctor. It is likely that her early entry into motherhood changed these aspirations. She went to an academically oriented high school from which she graduated at the age of 15 . There is considerable pride that the material gains of the family have come from the efforts, intelligence, and independence of Tanisha's mother. Although her father lives miles away, Tanisha sees him occasionally in the summers.

Tanisha was chosen for this project because she wrote in her autobiography that she was fascinated by rocks and had a rock collection. This interest in rocks made her more involved in science class, at times even doing projects that went beyond the requirements. However, Tanisha does not talk to her friends about her rock collection. It is just not the sort of activity she would talk to friends about. Tanisha began her rock collection in the fourth grade. Tanisha's mother encouraged this and bought her a book about rocks. She has thought that she might like to be a gemologist. Tanisha's mother also likes science. She graduated from high school with eight credits of science. Tanisha's mother encouraged her rock collecting and also spent time with Tanisha looking at Comet Hale when it was in the evening sky. Tanisha wrote eight pages about this in her journal, but threw it out before giving it to us.

Tanisha's engagement in school science can perhaps best be described as an effort to keep herself stimulated and involved in school. She participated frequently in class discussions in ways that accelerated their pace. If groupwork got too slow for her, she would find something 
more interesting to read. She engaged enthusiastically in group work that required physical as well as mental activity. She was disengaged when she was asked to read material she considered dull-such as the textbook. Disengagement at times led to frustration, boredom, and eventually a trip to the principal's office for disciplinary action.

Tanisha is a leader. In class, she knew the subject matter and was ready to participate. She demanded that she be called on when she had something to say. If she was not called on when she raised her hand, she usually called out the answer. Teachers typically responded to this by simply calling on her quickly when she raised her hand. When a friend of hers was slow to respond to a teacher's question, Tanisha yelled the answer to her. In small groupwork, she often took the lead role. Both her mother and her teacher note her strong leadership capacity.

Tanisha has extremely high expectations of the people around her. This was particularly apparent with her interactions with her teachers. During her seventh- and eighth-grade years, we observed her with three different teachers. Her first teacher was the most inquiry oriented. She gave the students interesting problems to solve in labs. Although Tanisha was at times difficult for this teacher, Tanisha responded positively to her instruction. When the teacher left in the middle of the year, the substitute had the students do little more than work out of the book. Tanisha complained loudly and bitterly to all who would listen.

Of all the girls in this study, Tanisha was the most sensitive to instruction. In fact, she was an almost perfect barometer of the quality of instruction. When Tanisha was bored, underestimated, or treated childishly, she responded with defiance. She is large, intelligent, and unwilling to tolerate work she considered to be trivial. She can show considerable anger. Tanisha got away with breaking rules for which other students would be punished. For instance, she chose her own assigned seat.

Tanisha is a serious basketball player and plays on community-based teams. As she matured, she was more likely to wear her hair in corn rows. Her friends are a mixture of both boys and girls, but almost exclusively African American. Whereas many girls this age have girlfriends they treat as friends, and associate with boys either as boyfriends or as someone to tease, Tanisha's interactions with boys and girls were similar. Tanisha's science teacher believed this to be a positive characteristic: "She has a strong personality and she is a very confident, strong individual ... she in no way is intimidated by any person, let alone by the opposite sex" (Eighthgrade teacher interview).

Tanisha was in the same science classes as Sheela for the seventh and eighth grades. The eighth-grade class contained students who were in upper-level math and language arts classes. Not surprisingly, Tanisha said that most of the students in her class were good at science. In comparison, Tanisha was a B/C student in science. At one point in the eighth grade her grades dropped to a C/D. When the teacher approached her about this drop in her grades, Tanisha's response was, "I'll bring it up" — and she did. Although Tanisha's eighth-grade science teacher recognized Tanisha's talent to be on a par with Sheela, she did not recommend her for the honors track in high school. Unlike Sheela, she would not describe Tanisha as self-motivated or independent.

\section{Cross-Case Analysis of Sheela and Tanisha}

These two girls are similar in terms of sex, race, social class, and family makeup. They even live in the same neighborhood. Virtually every background characteristic that is often used to explain school success and failure is the same for these two girls. Yet clearly, these background characteristics are not useful in predicting how these girls will engage in science. Sheela has many of the characteristics of the high-achieving Black girls in Fordham's study (1996). Although she is nearly invisible in science class, she always appears industrious. She is the kind 
of girl most often placed by teachers in honors tracks. She plays the role schools find acceptable and is rewarded for that behavior.

Tanisha, on the other hand, takes on different roles and identities in school. She is large and athletic and often behaves in ways that would be expected of boys. For example, her insistence that she be given the floor when she has something to say, and her defiance when underestimated are traits that are not typically associated with girls, especially the White (middle-class) girls that dominate this school. She is loud, like many of the African American girls Fordham (1997) described. In other words, Tanisha is breaking with certain gender conventions. She is not the kind of girl found in high school honors track classrooms.

Finally, although Sheela and Tanisha have different identities as students, they both responded most positively to the same kinds of instruction. They were both most engaged in science instruction that was inquiry oriented and were both least engaged with instruction that consisted of reading a section from the book and answering the questions at the end. However, whereas Sheela tolerated poor instruction, Tanisha did not. Whereas Sheela played the role of good student and did as she was asked regardless of the instruction, Tanisha would get in disciplinary trouble when instruction was poor. Although Sheela and Tanisha took classes together, we never saw them as much as speak to one another.

\section{Sandy}

Sandy lives with her father and stepmother in a new single-family home. She lives with her father during the school year and with her mother in rural North Carolina during the summers. She describes herself as African American. Her stepmother is a nurse and appears to be White or mixed race. Sandy's father is African American and repairs biomedical equipment such as Xray machines. His hobby is working on cars and motorcycles in his garage. He attended trade schools and considers himself as being good at science.

Sandy immediately garnered our attention when she wrote in her autobiography that she liked helping her father fix things and that she was most interested in school science when it dealt with subjects such as electricity as it related to the work she had done with her father. She is her father's only child. It appears as though in some ways she is being raised as boys traditionally have been-with considerable tutoring in all things mechanical such as helping her father with chores around the house and helping him out at work when he is at a hospital repairing a medical instrument.

Sandy's father sees her as being a lot like him. He believes her strengths are in her practical abilities rather than academic ones.

Anything that is moving or any changes going on, she wants to know what is happening and how's that work, you know. So that is probably where she gets it from. (Parent interview)

This is consistent with how Sandy sees herself. She said that she is good at "mazes, like puzzles, like things you can put together or like missing stuff." Sandy's father stated Sandy is more enthusiastic about a project than a written assignment. Sandy's interviews indicated that her father's assessment is on target. She said that she was not interested in science when it was just doing bookwork. She only became interested when she could do experiments. As she described at the end of her seventh-grade year:

When we did labs and I really wanted to do it and I tried to figure out how to do it, which way to go, how to put things together. My dad is a biomedical technician and he works 
on machinery. So he has to know all this stuff, like volts and everything else. That's when I wanted to start and got interested. (Student seventh-grade interview)

Of all the girls in this project, Sandy seemed to have the most strongly held view of science as a problem-solving endeavor. In the eighth grade, her interests expanded beyond electricity. She found learning about the cell and diseases to be interesting. She enjoyed making three-dimensional models of DNA and RNA and strongly valued the problem solving she was allowed to do.

It's fun. We do a lot of labs. She lets us figure things out for ourselves. She doesn't give us exact instructions. She gives us a chance to experiment with stuff. (Student eighthgrade interview)

Although Sandy enjoyed these aspects of school science and saw herself as good at it, not all school science work was inherently interesting to her. Furthermore, her seventh-grade year was a troubled one in which she failed many of her subjects, primarily owing to not handing in assignments. As a result, either her father or stepmother called her science teacher every 3 weeks during her eighth-grade year to check on Sandy's performance. She was typically a B student. Sandy participated actively in class and made friends easily. Sandy's eighth-grade science teacher described her as follows:

Sandy will talk to anybody. She is like a little puppy ... someone who is very lovable, someone who is very easily excited ... whenever she has something to say she'll just say it. (Eighth-grade teacher interview)

Sandy said that sometimes her friends are interested in science; at other times they are not. Sandy is good friends with Tanisha. They chatted in the halls between classes and sat together at focus group meetings and pizza parties. Sandy was less friendly toward the other members of the research team and less participatory in our activities when she was with Tanisha than when she was not.

Thus, more than the other girls, Sandy performed differently for various audiences. She seemed to want to be what others wanted her to be. This can perhaps be best illustrated when she talked about her future. She said that she had considered being "like my dad." She had also considered her grandfather's suggestion that she be a nurse or doctor, and her stepmother's suggestion that she be an artist (because she likes to draw). However, none of these suggestions appear to have originated from Sandy. She did not give much thought to where to go for high school or college because she said her parents would make that decision.

Sandy's father stated that the most important thing for Sandy as an adult was that she have a job she likes. He feels fortunate to have found this for himself. As discussed previously, Sandy's father believes her strengths are in her practical skills rather than academic abilities. Thus, he does not see college in her future. He believes a trade school would be better for her. Although he did not name a particular high school for her, he was clear that he wanted her high school to teach her practical skills with computers. He sees himself as also being good with computers and said that he will also teach her what she needs to know. In particular, he wanted her to be able to "get around Windows 95 and Office 97." Thus, it appears as though even though she has had some home tutoring in mechanical skills commonly associated with blue collar work, he sees his daughter entering more traditional female working-class fields that can be better described as pink collar. 


\section{Cross-Case Analysis of Sandy, Tanisha, and Sheela}

Sandy had many of out-of-school experiences that would be more typical of a boy. As her father's only child, she had access to experiences with mechanical things that many girls do not get. In some respects, this may have provided an advantage to her in that she enjoyed the opportunities science provided for using some of her skills in figuring out how things work. However, these out-of-school experiences for Sandy did not have the same effect as it might for a boy. It may well provide a working-class identification, but regardless of the mechanical skills Sandy may have, she is still a girl and thus does not accrue the same advantages from these experiences as a boy might. Furthermore, the problem-solving approach Sandy takes to engaging in science also does not help her as much as it could, because she constructs these talents in opposition to academic talents.

Sandy and Tanisha both had significant out-of-school, science-related experiences. They were chosen for the project because we believed they had particular inclinations toward science as a subject. Sheela, on the other hand, is good in science just because she is good in all school subjects. Clearly, the schools seem far better able to capitalize on Sheela's overall good student identity than they are the scientific identities of Tanisha and Sandy. Despite these different identities and views of science and school, all three had similar proclivities to hands-on instruction and, to a varying degree, a dislike for bookwork.

\section{Chandra}

Chandra lives with her mother, father, and younger sister in a large single-family home on a large lot in a racially integrated middle-class neighborhood. The house is new, spotless, and nicely furnished. Her parents work at the same large bank. Her father is in a management-level position. Of all the girls, Chandra appears to come from the wealthiest family. Her father is originally from Granada. Chandra says she has a close relationship with both of her parents, particularly her mother.

Chandra is gregarious, confident, and articulate. She expects people to listen to her and expresses her views openly and deliberately. When Chandra's science teacher showed a portion of the movie Roots to her class, Chandra laughed raucously at a scene involving ritual circumcision, and cried without embarrassment during a poignant scene. She gave an indignant response to a statement in the movie (and repeated by classmates) that a woman should not tell a man what to do.

She was one of a very few students chosen at Plotkin Middle School to be in the role of conflict mediator for the school. This was considered an honor. Of the girls in our project, Chandra was the only one who clearly articulated the existence of peer groups at school. She identified them as "gossips, social kids, and then sports." She described herself as belonging to the first two groups. She was an important person in the social groups of the school and had a large number of friends who depended on her for emotional support during times of crisis. In fact, her journal writing had little science in it. She mostly wrote about her numerous and intense peer relationships. Despite her strong social connections, she was not particularly strongly influenced by negative peer pressure.

Like, my friends, if they're not all that interested in school then they try to get me to do the same thing. Some of my friends are like that, but sometimes I just push them off. I don't really want to do that type of stuff. (Student seventh-grade interview)

Although Chandra is a well-rounded kid, she did not work very hard on academic tasks. At times, she could be seen scrambling right before class to get what she needed for her homework 
to be complete. B's were easy grades for her to earn, and also good enough. She is an average student and that is what she aspires to be. Her grades reflected her aspirations. There was no anxiety or pressure to get better grades in school. It is assumed by Chandra and her parents that she will go to college. Both parents and Chandra seem to think that at least so far, everything is on track for Chandra to get the education they aspire for her. After all, average students do go to college.

Chandra is the only one of these four girls to have been taught by Ms. Dawson for seventhand eighth-grade science. She was clearly one of the science teacher's favorite students. She played along with the teacher's jokes and participated in a surprise baby shower for her. Her science teacher described her as follows:

She is the laziest one of all of them. She is also one of the sweetest kids you'll ever meet ... and in my opinion she is the best politician because she can B.S. her way in and out of anything. And that is her biggest skill. Academically, she could do, oh, $300 \%$ better. But there's not a focus and that causes her some problems. Now in terms of maturity and talking the talk and all of that, outstanding. (Eighth-grade teacher interview)

This ability to "B.S. her way in and out of anything" served her well in the sixth-grade science fair. She described how she was chosen as a representative from her class, as follows:

We made flight poster board, turned off all the lights, shut the blinds, and we went to A.C. Moore and got glow-in-the-dark stars. And everybody loved that. And we got these nice balls and put glow paint and everybody loved that. . . . I just loved it. It's my best memory of the three years at that school. (Student seventh-grade interview)

Once she got to the science fair, she realized that she knew the judges and could "suck up" to them: "If we didn't do that we weren't going to win anything, but we won fifth place and got little trophies."

Chandra defined science very broadly. In her initial autobiography, she wrote, "science is life" and "I'm part of science and I like science." The following year, when talking about the television shows she watched, she identified science as being a part of all of them. (Given Chandra's people-pleasing tendencies, this view may have been an expression of what she thought the researchers wanted to hear.) Chandra enjoyed people and considers psychology a science. Thus, all of her television watching was science related.

Chandra sees herself as a "people-person" and enjoys science most when working in groups. She likes experiments and the opportunities to talk to people. However, often during the experiments Chandra was not the one taking charge of the materials. Rather, she served as scribe, talking all the while. Other students comment that Chandra was not a hands-on person.

Chandra talked most articulately about science when she was talking about the science background related to a human problem. For example, she described the genetics behind elephantitis after the science class saw Elephant Man. She talked in some detail about how her mother got gangrene and what was done about it. She understood how her brand-new house got "a little rodent problem" and described in some detail a group project in school in which they made a tornado in a bottle. In essence, when she was interested in something she engaged the science needed to understand it. In contrast, she was unable to figure out how to find the average high temperature in Boise, Idaho, for one of her science projects.

\section{Cross-Case Analysis of Chandra, Sandy, Tanisha, and Sheela}

Chandra clearly defined herself as an average student who is going to college and will be successful. There was no self-doubt, nor was there doubt from her parents or teachers but that 
Chandra will be successful. Of all the girls in this project, Chandra was the only one whom we would describe as having college assumptions rather than merely college expectations. There is a certain amount of stress involved with school when you are expected to go to college, particularly if you are expected to go to college yet must qualify for financial aid and be able to forego earning income while in college. Not only does the financial situation of Chandra's family provide her with relief from worry about college, she also performed adequately and is very well liked by both teachers and peers. She will have no difficulty getting good letters of recommendation and having activities such as participating in this project as part of her application for college.

Whereas Tanisha would never suck up to anyone, Chandra was good at it and used her skills to win the science fair. Whereas Chandra threw parties for her teachers, Tanisha gave teachers a hard time when the science lesson was not up to her high standards. Although Chandra was an average science student, she was still admired by teachers for being a sweet, well-rounded kid.

Chandra is the only one of these four girls who is clearly middle class. She also seems most adept at negotiating school culture in ways that are neither mere compliance nor rebellion. In other words, she negotiates the borders between home, school, and school science smoothly (Aikenhead, 1996).

\section{Conclusions}

These cases illustrate a variety of kinds of girls and how they engage in science. All four cases deviate in substantive ways with the stories commonly told about girls in science. These girls are not alienated from science and they all believe they are good at science. Some of them are mechanically oriented or outspoken, and choose to engage in science outside of school. To some extent all of the girls had identities that overlap in important ways with science.

Sheela is a good student. Although her identity has no strong science-specific component to it, it overlapped almost completely with the social role of good student. For Sheela, there appears to be no struggle in reconciling who she is with what was required of her in science classes.

Sandy is good at figuring out how things work, an identity that served her well in some of the lab experiments she was asked to do in school. However, because it is also an identity that does not overlap well with academic talent, and science is not only practical but also an academic subject, her identity also limited her engagement in science.

Tanisha is a leader and someone who has ideas and should be heard. Because of this identity, Tanisha was a leader in her class who was taken seriously by both students and teachers. Despite Tanisha's obvious competence in science, problems occasionally arose because Tanisha's identity overlapped poorly with the identity of the good student.

These different identities certainly affected the ways the girls engaged in school science. Sheela, like many good female students, is quiet. Tanisha and Sandy, on the other hand, often participated in classroom discussions. Tanisha did so assertively. Although she seems to recognize her own competence, we also believe she has little desire to take up a good student identity that would also serve to silence and bore her. Chandra also participates in classroom discussions, although her contributions were less substantive than Sandy's or Tanisha's. Tanisha, Sandy, and Sheela were all far more interested in science when they were involved in some type of lab activity. Tanisha and Sandy especially benefited from this. Tanisha and Sheela often took up leadership roles in these settings. However, beyond this, the instruction did not allow for a wide variety of ways to engage in science. Although most of the girls talked in science class, we never heard them ask a science-related question. The curriculum was not sufficiently flexible to allow students to pursue different aspects of a problem or devise a variety of ways of showing what they know. For the most part, their choices were limited to whether to complete 
the task assigned. We suspect, however, that the girls could benefit from a curriculum that permitted more diversity in the ways students might engage in and use science content.

It may be tempting for science education researchers to ask whether the girls participated in science in ways that lead to understanding. Interestingly, neither the students, teachers, nor parents talk about understanding when they are talking about success in school science. We saw little evidence of much struggle to understand an idea in science class. Success was judged mostly on grades and participation in class. Understanding was not a high priority and appeared to play a marginal role in students' constructions of identity, a finding consistent with other research (e.g., Rop, 1999).

Chandra is an average student and a people-person. Her identity as an average student set a clear and reachable goal for her in science class. Her view of herself as a people-person allowed her to use her social skills to succeed in science class. Although we see Chandra as largely successful in science, we also wonder whether this may have been due in part to a particularly good fit between herself and her science teacher. Her teacher, Ms. Dawson, was also particularly strong in social skills and liked and encouraged students like Chandra. Because we saw her only as a student in Ms. Dawson's class, we do not know how well she would fare in a classroom that was more focused on more in-depth understandings of science.

At least for now, it appears as though the teachers respond much more positively to Sheela and Chandra than they do to Tanisha and Sandy. In other words, the two girls who take on easily recognizable social roles for girls and bring with them the usual experiences and talents of girls are also the ones who have the fewest difficulties in constructing successful school science identities. Whereas all four of these girls constructed positive identifications with science, schools and teachers do not respond to these identities in value-neutral ways. The girls' identities are personal, yet also have significant political consequences. Violating school-sanctioned gender norms of what a good student is may have negative academic consequences. This seems to be the case even when the identities schools select against are potentially advantageous for succeeding in science, e.g., being good with puzzles, assertiveness, engaging in science outside of school.

This raises the question of whether girls who are being encouraged to continue in high-level science in the short-run-like Sheela - are actually the ones who are most likely to stay engaged in science over the long term. We would be surprised, but pleased, if Sheela continued in science beyond the compulsory courses. Although she is successful in school science, she has no particular interest in it that goes beyond participating in science class as part of being a good student. Tanisha and Sandy, however, clearly have strong scientific interests. Furthermore, we wonder whether their willingness to violate gender norms might not make them better able to withstand the sexism of the scientific workplace (Eisenhart \& Finkel, 1998) than women who conform more to gendered societal expectations.

We worry about the consequences of tracking for Tanisha and Sandy. This study illustrates how decisions are made in tracking students for high school science. These decisions were made by the eighth-grade teacher, given criteria from the high schools regarding student expectations. The top track science classes were largely reserved for students who were considered well behaved and completed their work on time. Selection was based more on what the school wanted than on what the student needed. Tanisha, for example, may not be the most obedient student, however, she needs to be challenged in science class. If she is not put in classes that will challenge her, there is a high risk that she may give up on school altogether.

We question, as well, the consequences of research that considers girls only in comparison to boys. We wonder whether this research has exaggerated the differences between girls and boys and not attended to the diversity within these groups. Furthermore, if this difference in research is presented to teachers as the way girls are, teachers may fail to recognize and under- 
stand the identities of girls not falling into the predictable stereotype. In particular, girls such as Tanisha and Sandy are completely invisible and unaccounted for in the research story we we told at the beginning of this article.

There are still many things we do not know. We do not know the degree to which it is the case that all girls who violate gender expectations have more difficulty taking on school science identities. We also do not know whether the same identities described here that limit the degree to which girls take on scientific identities also affect boys. However, what we do know is that when teaching girls science and trying to explain why it is they are or are not doing well in science, we need to know more than that they are girls. We need to know what kinds of girls they are.

\section{Postscript}

Sheela surprised us when we saw her as a ninth-grader. She had transformed herself from a tidy, young-looking middle schooler to a sophisticated, mature-looking high schooler. She was placed in a heterogeneous earth science class as part of an experiment in her high school to see whether de-tracking might improve student performance. She seemed unaware that this was a mixed class rather than one for honors students only. Her science teacher was young and innovative in his teaching and held the class to high standards. Sheela has some difficulty adjusting to his routines and initially did poorly. However, by the end of the year she had adjusted to the new expectations and was preparing for Honors Biology in the 10th grade.

Tanisha was placed in a middle-track earth science class for ninth grade. At the beginning of the year she was extremely irate that her science teacher spent most of his time at his desk or talking on the telephone rather than teaching. By December she was complacent about her science class. By May she was considering dropping into the lowest-track science class for 10th grade.

Sandy was also placed in a middle-track earth science class. Although her teacher tried hard to engage the students in learning about rocks and geological formations and the like, his instruction did not include much of the problem-solving approaches Sandy had enjoyed in middle school. Furthermore, her parents no longer closely monitored her schoolwork and Sandy did not have the motivation to complete her work in the absence of her parents.

Chandra transferred to a different district and took a middle-track physical science class. The teacher's curriculum was traditional in content and taught in a theater-style classroom. Given these conditions, we were surprised that he included some small-group work in addition to lectures and demonstrations. The science teacher focused more narrowly on students' content learning than had been the case for Chandra's eighth-grade teacher. He was far less sanguine about Chandra's future than Chandra's middle school teacher, although Chandra seems as optimistic about her future as before.

Future research will describe these and other changes in the girls' identities as they mature.

This research was assisted in part by a grant from the Spencer Foundation. Special thanks to Glenn Aikenhead, William J. Letts, Pamela Perdue, Harry Shipman, and Polly Steenhagen for discussions and comments regarding this work. The data presented, the statements made, and the views are solely the responsibility of the authors.

\section{References}

Adamson, L.B., Foster, M.A., Roark, M.L., \& Reed, D.B. (1998). Doing a science project: Gender differences during childhood. Journal of Research in Science Teaching, 35, $845-858$. 
Aikenhead, G.S. (1996). Science education: Boarder crossing into the subculture of science. Studies in Science Education, 27, 1-52.

Baker, D. (1998). Equity issues in science education. In B.J. Fraser, \& K.G. Tobin, (Eds.), International handbook of science education (pp. 869-896). Boston: Kluwer.

Belenky, M.F., Clinchy, B.M., Goldberger, N.R., \& Tarule, J.M. (1986). Women's ways of knowing: The development of self, voice, and mind. New York: Basic Books.

Brown, J.S., Collins, A., \& Duguid, P. (1989). Situated cognition and the culture of learning. Educational Researcher, 18, 32-42.

Costa, V.B. (1995). When science is "another world": Relationships between worlds of family, friends, school, and science. Science Education, 79, 313-333.

Duit, R., \& Treagust, D.F. (1998). Learning in science: From behaviorism towards social constructivism and beyond. In B.J. Fraser \& K.G. Tobin (Eds.), International handbook of science education (pp. 3-26). Boston: Kluwer.

Eisenhart, M.A., \& Finkel, E. (1998). Women's science: Learning and succeeding from the margins. Chicago: University of Chicago Press.

Fordham, S. (1997). "Those loud black girls": (Black) women, silence, and gender "passing" in the academy. In M. Seller \& L. Weis (Eds.), Beyond black and white: New faces and voices in U.S. schools. Albany, NY: SUNY Press.

Fordham, S. (1996). Blacked out: Dilemmas of race, identity, and success at Capital High. Chicago: University of Chicago Press.

Gaskell, P.J., Hepburn, G., \& Robeck, E (1998). Re/presenting a gender equity project: Contrasting visions and versions. Journal of Research in Science Teaching, 35, 859-876.

Goffman, E. (1958). Presentation of self in everyday life (Monograph No. 2.). University of Edinburgh, Social Sciences Research Centre.

Greenfield, T.A. (1996). Gender, ethnicity, science achievement, and attitudes. Journal of Research in Science Teaching, 33, 901934.

Kahle, J.B., Parker, L.H., Rennie, L.J., \& Riley, D. (1993). Gender differences in science education: Building a model. Educational Psychologist, 28, 379-404.

Krockover, G.H., \& Shepardson, D.P. (1995). Editorial: The missing links in gender equity research. Journal of Research in Science Teaching, 32, 223-224.

Lave, J. (1998). The culture of acquisition and the practice of understanding. In D. Kirshner \& J. A. Whitson (Eds.), Situated cognition (pp. 17-36). Mahwah, NJ: Erlbaum.

Lave, J. (1992, April). Learning as participation in communities of practice. Paper presented at the annual meeting of the American Educational Research Association, San Francisco.

Lloyd, B., \& Duveen, G. (1992). Gender identities and education: The impact of starting school. New York: St. Martin's Press.

Park, R.E. (1950). Race and culture. Glencoe, IL: Free Press.

Rennie, L. (1998). Gender equity: Toward clarification and a research direction for science teacher education. Journal of Research in Science Teaching, 35, 951-961.

Rop, C. (1999). Student perspectives on success in high school chemistry. Journal of Research in Science Teaching, 36, 221-238.

Roseberry, A., Warren, B., \& Conant, F. (1992). Appropriating scientific discourse: Findings from language minority classrooms. Journal of the Learning Sciences, 1.

Shapiro, B. (1994). What children bring to light. New York: Teachers College Press.

Taylor, P.C. (1998). Constructivism: Value added. In B.J. Fraser \& K.G. Tobin (Eds.), International handbook of science education (pp. 1111-1126). Boston: Kluwer.

Weedon, C. (1987). Feminist practice and poststructuralist theory. Cambridge, MA: Basil Blackwell. 